\title{
Economic feasibility of wind and photovoltaic energy in Kuwait
}

\author{
Waleed K. Al-Nassar ${ }^{1, *}$, S. Neelamani², and Teena Sara William² \\ ${ }^{1}$ Energy and Building Research Centre, Kuwait Institute for Scientific Research, P.O. Box: 24885, Safat 13109, Kuwait \\ ${ }^{2}$ Environment and Life Sciences Research Centre, Kuwait Institute for Scientific Research, P.O. Box: 24885, Safat 13109, Kuwait
}

\begin{abstract}
The worldwide environmental concern and awareness created a way towards the generation of pollution-free wind and solar renewable energies. Wind and Photovoltaic (PV) power plants of each $10 \mathrm{MW}$ capacity located in the Shagaya area, west of Kuwait, were compared after one year of operation. The wind power plants recorded high capacity factors resulting in a yearly power production of $42.59 \mathrm{GWh}, 21 \%$ higher than expected (contractual $31.160 \mathrm{GWh}$ ). It will reduce the emission of $\mathrm{CO}_{2}$ throughout the projected lifetime of 25 years by 118,303 tons. CAPEX (capital Expenditure) and OPEX (operation expenditure) were taken into consideration throughout the life of the plants along with investment costs resulting in a levelized cost of electricity (LCOE) for wind of $0.015 \mathrm{KWD} / \mathrm{kWh}$ or $0.046 \mathrm{USD} / \mathrm{kWh}$, compared to $0.027 \mathrm{KWD} / \mathrm{kWh}$ or 0.082 $\mathrm{USD} / \mathrm{kWh}$ for solar PV (44\% lower than PV). Offshore, Boubyan Island, Northern Kuwait territorial waters, were found to be the foremost appropriate for wind energy generation, with Wind Power Density of more than $500 \mathrm{Watt} / \mathrm{m}^{2}$ in summer which is ideal for the high energy demanding season in Kuwait. The LCOE for offshore wind energy was $27.6 \mathrm{fils} / \mathrm{kWh}$, compared to $39.3 \mathrm{fils} / \mathrm{kWh}$ for thermal power plants.
\end{abstract}

\section{Introduction}

A move towards pollution-free renewable energy, particularly wind power and solar energy generation, has generated global concern and environmental awareness. Wind energy potential analysis requires thorough statistical evaluation of wind characteristics such as mean wind speed and frequency distribution [1-2].

The Shagaya area, west of Kuwait, hosts the first renewable energy power plant that combines three different technologies in the Arabian Gulf area. Wind energy, photovoltaic and consecrated solar power (CSP). Dust storms play a big role in renewable energy technology performance and efficiency. Depending on the area and the climate, some areas have more sand storms than others. In the Shagaya location, wind is fairly high. As this location is an open desert location, sand storms are very common and have different effects on the two technologies in question, wind and photovoltaic. The wind turbines in the Shagaya power station were optioned with a high temperature package that allows more air flow to pass through the nacelle, ultimately allowing the dissipation of heat, however, this means more dust in the air filters of the nacelle, which in turn could cause blockage of the air flow and hence increasing the nacelles components (gearbox and hydraulic systems etc.) temperature. This may affect the operation availability and allowable down time where energy may not be produced.

When it comes to photovoltaic (PV) cells, dust may cause calcification on the top surface of cells. This may reduce the cell's efficiency if not immediately cleaned. Water in the desert is also scares and very hard to come by. With all the above mentioned effects on the performance of renewable energy technologies in question in open desert climates, economic feasibility of the technologies may determine the choice of renewable energy technology that would be more favourable for such climates [3].

The main aim of this paper is to compare the economic feasibility of wind and Photovoltaic (PV) power plants, each of $10 \mathrm{MW}$ capacity located in the Shagaya area, west of Kuwait, after one year of operation. The annual power production, CAPEX (capital Expenditure) and OPEX (operation expenditure) were taken into consideration for the designed life span of these plants along with Investment costs resulting in one figure, known as LCOE (levelized electricity cost). From this analysis, it is possible to understand which one is better (wind power or PV based power production) for country like Kuwait with high annual temperature variation ( 5 to 52 degree $\mathrm{C}$ ) and with high suspended dust concentration in air.

\subsection{Mean monthly wind speed and expected annual power production}

The Shagaya area is situated on the western side of Kuwait with 280 meters above mean sea level. This is causing airstream over the location to be compressed. This area is exposed year round to higher wind velocities than the urban areas of Kuwait. Based on the meteorological data in Shagaya Wind Farm, the average monthly wind speed is around $7.8 \mathrm{~m} / \mathrm{s}$, as shown in Table 1.

\footnotetext{
* Corresponding author: wnassar@kisr.edu.kw
} 
Table 1. Average monthly wind speed and the Monthly (gross) power production in Shagaya wind farm during the first year of operation/

\begin{tabular}{|l|c|c|}
\hline Month & $\begin{array}{c}\text { Average wind speed } \\
\text { (m/s) }\end{array}$ & $\begin{array}{c}\text { Power production } \\
\text { (Kwh) }\end{array}$ \\
\hline Aug-17 & 8.0 & $4,179,365$ \\
\hline Sep-17 & 6.9 & $3,822,571$ \\
\hline Oct-17 & 7.2 & $3,174,254$ \\
\hline Nov-17 & 6.7 & $2,770,897$ \\
\hline Dec-17 & 7.8 & $3,948,152$ \\
\hline Jan-18 & 7.3 & $3,330,362$ \\
\hline Feb-18 & 7.0 & $2,876,305$ \\
\hline Mar-18 & 7.3 & $2,692,287$ \\
\hline Apr-18 & 7.2 & $2,624,838$ \\
\hline May-18 & 6.3 & $2,506,604$ \\
\hline Jun-18 & 10.2 & $5,192,837$ \\
\hline Jul-18 & 11.1 & $5,471,524$ \\
\hline
\end{tabular}

This $10 \mathrm{MW}$ wind power plant consists of 5 turbines, each of 2.0 MW capacity. It has recorded an annual power production of $42.59 \mathrm{GWh}$ gross total power (contractual $31.160 \mathrm{GWh}$ ) which is $21 \%$ higher than expected. As for the PV of $10 \mathrm{MW}$ capacity, expected annual energy production is estimated to be $18.85 \mathrm{GWh}$ gross total.

\subsection{Wind farm capacity factor}

Fig. 1 below shows the monthly calculated capacity factor obtained during the first year of operation for the wind farm. June and July of 2018 are near record numbers ever recorded worldwide by industry standards, 68\%-70\%. The wind speed is comparatively high and it is sustained during these months. This has resulted in high capacity factor. In this figure, the five different colors for each month indicate the capacity factor of each $2 \mathrm{MW}$ wind turbines.

Based on the capacity factor evolution observed, the Capacity Factor for the Shagaya wind farm is expected to be above $40 \%$. Note that the standard capacity factor for on-shore wind farms are, on average, $25-35 \%$. Comparing the first month of operation, July of last year with July of this year (2018), Fig. 2, there is a great difference in performance as that first 6 months are dedicated to adjust and improve wind farm performance. Therefore, availability was low (below the contractual, 95\%) during the first few month as can be seen in Fig. 2. With these information, the aim of this paper is to reveal the economics of wind and PV power generation based on one year power production from the wind mills and PV plants of $10 \mathrm{MW}$ capacity in Kuwait.

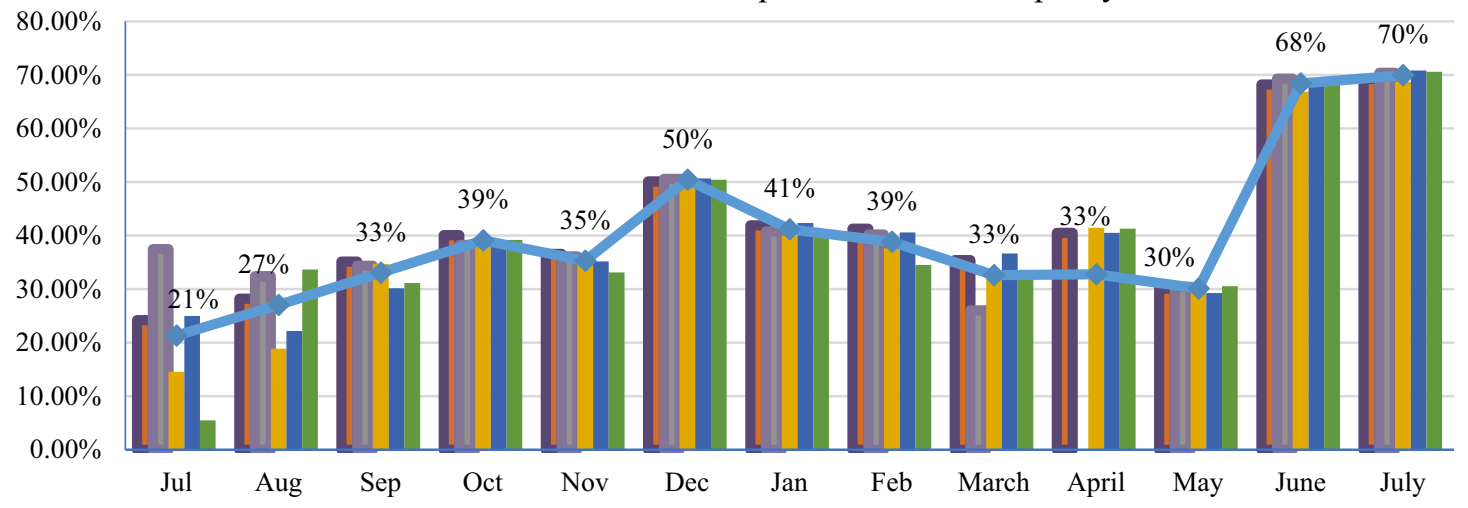

Fig. 1. Monthly Capacity Factor.

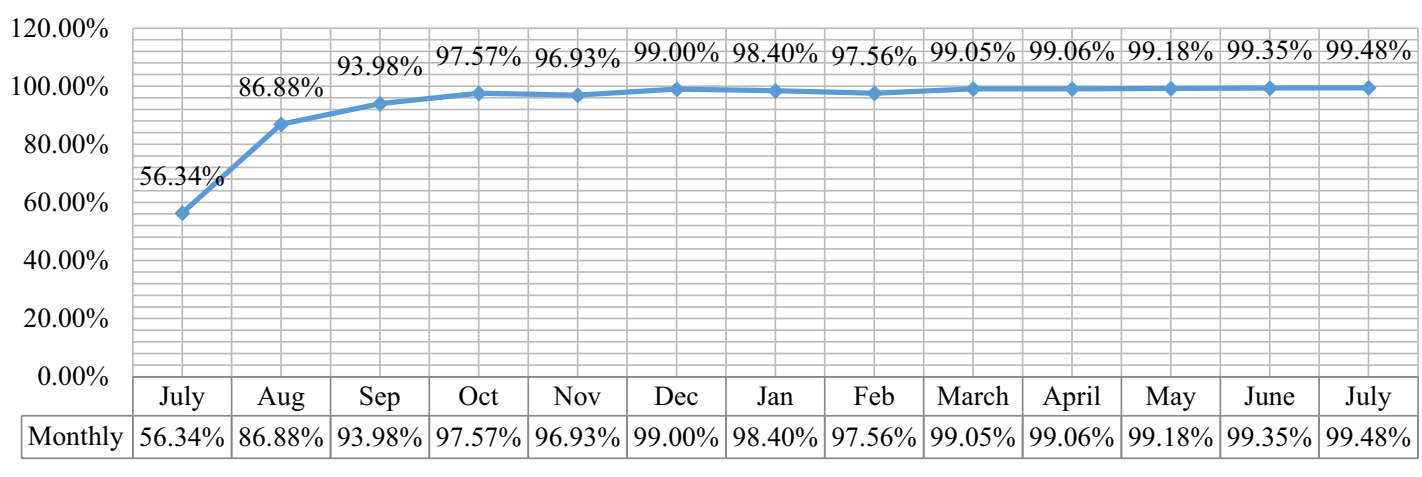

$\longrightarrow$ Monthly

Fig. 2. Kuwaiti 10 MW Wind Farm - Monthly Average Availability.

\section{Methods}

The present work is focused on the economic analysis based on actual power generation for 1 year from wind and PV plants of each $10 \mathrm{MW}$ installed in Kuwait. The economic analysis results are projected based on
Levelized Cost of Electricity (LCOE). The purpose of this is to encourage investment in projects, which promote the most efficient use of a nation's resources. As the economic analysis is done from the point of view of the national economy, inflation, customs, duties, and other factors, which distort market prices are not taken into consideration. The objective of the economic analysis is 
to calculate the cost of electricity supply of these options for the Kuwaiti national economy.

\subsection{Economic analysis approach}

LCOE is derived by dividing the present value of the project costs at economic prices by the present value of the quantity of power generation. It thus represents the specific energy generation cost over the entire project life cycle. Mathematically, the LCOE is described as follows:

$$
=\frac{\sum_{t=0}^{n} \frac{C_{t}}{(1+i)^{t}}}{\sum_{t=0}^{n} \frac{E_{t}}{(1+i)^{t}}}
$$

Where:

- $C_{t}$ is the project costs incurred in year $t$

- $E_{t}$ is the power generation in year $t$

$-i$ is the economic discount rate

$-n$ is the number of years in the period under consideration.

After calculating the LCOE, a subsequent step will assess the financial feasibility of the WTG project. In the future situation with these projects, wind or PV energy replaces energy that in the absence of these projects would otherwise have to be generated by conventional (thermal) power plants. The energy produced by the projects thus serve to avoid the costs of thermal generation of the equivalent amount of energy. The benefit derived from this avoided cost consists solely of the energy benefit, which comprises the avoided operating costs of the alternative, i.e., fuel costs and variable operation and maintenance costs. Furthermore, $\mathrm{CO}_{2}$ emissions are foregone as a consequence of this avoided fuel consumption. The benefit through capacity replacement is evaluated with the average specific CAPEX of the Ministry of Electricity and Water (MEW) planned thermal power plants to be built until 2023 and counts for USD 1,650/kW (1,146 EUR/kW). The benefits accruing to the project include the following:

- Inescapable fuel utilization

- Foregone variable operation and maintenance costs

- Environmental benefits $\left(\mathrm{CO}_{2}\right.$ savings)

- Replacement of conventional generation capacity.

These benefits materialize because the implementation of these projects effectively offset energy that would otherwise have to be produced by thermal power plants.

Within the context of the economic analysis, the generation in thermal power plants would be calculated with the following assumptions:

- Average electrical efficiency: $42 \%$. This corresponds to the average electrical efficiency of the planned conventional power plants in the medium term in Kuwait.

- Fuel price: USD 13.59 2010/GJth. Average annual increase: $1.8 \%$.

- Fuel specific $\mathrm{CO}_{2}$ content: $15.3 \mathrm{~kg} \mathrm{CO} / \mathrm{GJ}$ th, according to IPCC.

- Price of $\mathrm{CO}_{2}$ emissions: USD $10 / \mathrm{t} \mathrm{CO}_{2}$. This price reflects current market prices for emission allowances in international carbon stock markets.

\subsection{Project costs}

In general the investment costs for wind farms comprise the following items:

- Purchase price for wind turbines (WTGs) and PV cells, ex-works.

- In the case of wind energy, purchase price for WTG towers, in case it is excluded from the aforementioned item.

- $\quad$ Purchase price for MV (step-up) transformer, in case it is excluded to the aforementioned items.

- International and local transportation.

- Supervisory Control and Data Acquisition System (SCADA), in case it is excluded from the aforementioned items.

- Civil works (control room and substation building, administration, workshop and other buildings).

- Access roads (in most cases a width of $8 \mathrm{~m}$ ) and cable trenches.

- Foundation works (in case it is excluded in the turbine price and PV price).

- Electrical works (grounding, cabling, substation, transformers).

- Engineering and installation supervision (consultancy services, construction supervision, as well as project management).

- Miscellaneous (computer and network, working table and accessories, printers, fax, phone lines, security, purchase of land, etc.).

\subsection{Operation and maintenance costs}

Operational expenditures for the wind and therefore the PV farms arise from the following:

- Fees for O\&M Contract

- Spare Components

- Insurances

- Administration

\subsection{Net present value}

The Net Present Value Approach (NPV) is a decision tool generally used to measure the long-term financial costs and benefits of a project by considering the money's time value. The time value of money essentially indicates that at some point in the future, a dollar earned today is worth more than a dollar earned, since the dollar received today can be spent to gain interest. The potential net cash flows of a project are discounted by a rate called discount rate to measure the time value of a project, which is a percentage representation of how much more a dollar is worth to the project funded today than next year, which may indicate other variables such as the project's perceived danger which expected escalation variables over the estimated NPV era. The time value of cash depends on a variety of variables, including net cash flows, the period of estimation of the NPV and the discount rate[5]. NPV 
estimates find the current value of the potential net cash flow of a project in today's dollars, enabling that amount to be compared with the amount of money needed to execute the project. Cash Flow is a project 's income minus the project's expense for a given year.

$$
N P V=C_{0}=-I_{0}+\frac{C F_{1}}{1+i}+\frac{C F_{2}}{(1+i)^{2}}+\ldots+\frac{C F_{t}}{(1+i)^{t}}=-I_{0}+\sum_{t=1}^{n} \frac{C F_{t}}{(1+i)^{t}}
$$

Where,

- $\mathrm{I}_{0}$ is the Investment in time $\mathrm{t}=0$

- $\mathrm{CF}_{\mathrm{t}}$ is the cash out - flow in $\mathrm{t}$

- $\quad t$ is the period (year)

- $0 \leq \mathrm{t} \leq \mathrm{n}$

- $\quad \mathrm{i}$ is the discount rate

\subsection{Future value of money}

The financial ROR is an indicator to measure the financial return on investment of an income generation project. It is obtained by simply rearranging the time value of money equation,

$$
F V=P V(1+i)^{t}
$$

Where,

- $\mathrm{FV}$ is the future value of money

- $\quad \mathrm{PV}$ is the present value of money

- $\quad t$ is the period (year)

- $0 \leq \mathrm{t} \leq \mathrm{n}$

- $\quad \mathrm{i}$ is the discount rate and effectively in this case ROR

\subsection{Payback period}

The payback period is simply the time required to recover the initial investment at the beginning of the project.

\section{Economic analysis results}

The economic output of the wind project was focused on MEW's reference fuel price scenario. The Net Present Value (ENPV) is positive because of the relatively low CAPEX and OPEX of the WTG project and the relatively high energy production, indicating that the investment is profitable for the Kuwaiti economy. This can also be seen in the Rate of Return (ROR), which is 8.5 percent and thus greater than the 7.0 percent basic discount rate.

\section{Solar photovoltaic (PV) vs wind energy}

The current Shagaya wind farm powers 450 houses, at the current annual household consumption of $94,500 \mathrm{~kW} / \mathrm{h} / \mathrm{yr}$ compared to 199 homes for PV. Reducing local and global emissions throughout the projected lifetime of 25 years by 118,303tons of $\mathrm{CO}_{2}, 2.3$ times higher than that of PV. As for potential power producing companies, the Shagaya wind energy power plant provides investors with $8.5 \%$ rate of return with a 5.36 year payback period. A comparison between the Levelized Electricity Cost (LCOE) of wind energy generation with the LCOE of photovoltaic power plants is essential. Fig. 3 below compares PV to On-shore wind energy. For the Shagaya wind energy power plant, Simplified LCOE obtained for Shagaya wind farm is 0,015 $\mathrm{KWD} / \mathrm{kWh}$, that represents an LCOE of 0,046 $\mathrm{USD} / \mathrm{kWh}(1)$, compared to $0,027 \mathrm{KWD} / \mathrm{kWh}$ or 0,082 $\mathrm{USD} / \mathrm{kWh}(1)$ for solar PV. Thus the LCOE value for wind energy is $44 \%$ less than that of PV.

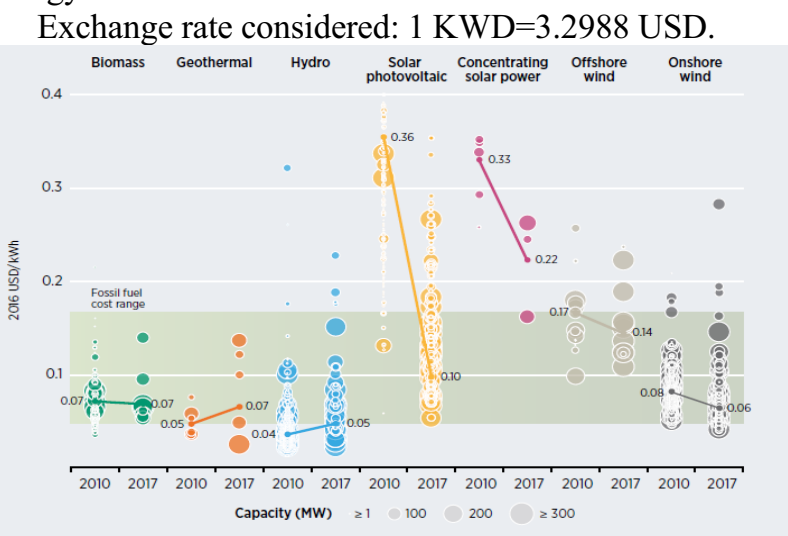

Fig. 3. Comparison of LCOE according to the technology implemented. Renewable power generation costs in 2017, [6].

Table 2. Depositional rates of dust fallout within major dust storm trajectories in the world from upwind to downwind.

\begin{tabular}{|l|c|c|c|}
\hline Zone-Location & Country & Ref. & Tons.km $\mathbf{- n}^{-2} \mathbf{y r}$ \\
\hline A long Niger River & Mali & $7[7]$ & $913-10446$ \\
\hline Northern Diarnena & Chad & {$[8]$} & 142 \\
\hline Kano & Nigeria & $9[9]$ & $137-181$ \\
\hline Southern Chad & Chad & {$[10]$} & 109 \\
\hline Nouadhibou & Mauritania & {$[11]$} & 80 \\
\hline Smara & Western Sahara & {$[12]$} & 111 \\
\hline Agadir & Morocco & {$[13]$} & 114 \\
\hline Sidi Ifni & Morocco & {$[14]$} & 145 \\
\hline Tan Tan & Morocco & {$[15]$} & 175 \\
\hline Dakhla & Mauritania & {$[16]$} & 191 \\
\hline Boujdour & Western Sahara & {$[17]$} & 219 \\
\hline Libya & Libya & {$[18][16]$} & 155 \\
\hline Negev Desert & Palestine & {$[19]$} & $57-217$ \\
\hline Crete & Greece & 20 & $10-100$ \\
\hline Fahal & Oman & {$[21]$} & 89 \\
\hline Riyadh & Saudi Arabia & {$[22]$} & 392 \\
\hline Dead Sea & Palestine & {$[23]$} & 45 \\
\hline Khur Al-Zubir & Iraq & {$[24]$} & 75.92 \\
\hline Um Qasr & Iraq & {$[24]$} & 193.47 \\
\hline Kuwait & Kuwait & {$[26]$} & 370 \\
\hline Xilingele & Mongolia & {$[24]$} & 292 \\
\hline Shapotou & China & {$[25]$} & 372 \\
\hline Tokyo & Japan & {$[26]$} & 3.5 \\
\hline Adelaide & Australia & {$[27]$} & $5-10$ \\
\hline Namoi valley & Australia & {$[27]$} & $16.9-58.2$ \\
\hline
\end{tabular}

The Fig. 3 below compares the LCOE of various renewable energy technologies worldwide. It can clearly been seen that the simplified LCOE of wind energy is approximately 50\% lower than expected LCOE values for solar photovoltaic, PV plants. For decision makers, a comparison between the Levelized Electricity Cost 
(LCOE) of wind energy generation with the LCOE of photovoltaic power plants is essential. Also, table 2 shows that deposited dust in Kuwait is one of the highest compared to regional and global scales. These amounts of deposited dust will surely act as a major challenge for the solar energy. Therefore, wind energy is the alternative and proper solution for future power generation in Kuwait.

From table 2, it is found that the dust deposit arte in Kuwait is about 370 Tons. $\mathrm{km}^{-2} \cdot \mathrm{yr}^{1}$. This dust deposits on PV surface is found to reduce the efficiency of PV power generation. It is also found that the calcification is as hard as the PV surface itself. This makes the surface cleaning difficult.

\section{Conclusion}

Wind and Photovoltaic (PV) power plants of each $10 \mathrm{MW}$ capacity was installed in the Shagaya area, west of Kuwait. This wind power plants recorded high capacity factors and has resulted in a yearly power production of $42.59 \mathrm{GWh}, 21 \%$ higher than the contractual value of $31.160 \mathrm{GWh}$. A detailed economic analysis is carried out based on the actual capital Expenditure, operation expenditure and is taken for the complete life time of these installed plants. Based o this analysis, it is found that the levelized cost of electricity (LCOE) for wind is 0.015 $\mathrm{KWD} / \mathrm{kWh}$ ( $0.046 \mathrm{USD} / \mathrm{kWh})$, compared to 0.027 $\mathrm{KWD} / \mathrm{kWh}(0.082 \mathrm{USD} / \mathrm{kWh})$ for solar PV (44\% lower than PV).

Kuwait Foundation for the Advancement of Sciences (Project No. P315-34SE-02) is thankfully acknowledged for its financial support. The authors are grateful to the Kuwait Institute for Scientific Research (KISR) senior management for the use of infrastructure facilities in carrying out this work.

\section{References}

1. A. Al-Awadhi, Renew. Ener. 30(14), 2149-2161 (2005)

2. W. Al-Nassar, S. Neelamani, Kuwait Institute for Scientific Research - EA060C, KISR 14978, (2018)

3. A. Al-Dousari, W. Al-Nassar, A. Al-Hemoud, A. Alsaleh, A. Ramadan, N. Al-Dousari, M. Ahmed, Solar and wind energy: Challenges and solutions in desert regions, Ener. 176(C), 184-194 (2019)

4. W. Al-Nassar, A. S. Alhajraf, A. Al-Enizi, L. AlAwadi J. Ljubic, Final Report - Kuwait Institute for Scientific Research - EC043K, (2007)

5. W. Al-Nassar, S. Neelamani and H. Al-Dashti, Ener. 169, (2019)

6. IRENA. Renewable Energy Statistics 2018. The International Renewable Energy Agency, Abu Dhabi. (2018) ISBN 978-92-9260-077-8.

7. M. Al-Dousari, M. Ahmed, N. Al-Dousari, S. AlAwadhi, Int. J. Env. Sci. Tech. 16, 2415-2426 (2019)

8. A. Al-Dousari, A. Aba, S. Al-Awadhi, M. Modi, N. Al-Dousari, Arab. J. Geosci. 9(2), 95 (2016)
9. M. Al-Dousari, M. I. Ibrahim, N. Al-Dousari, M. Ahmed, S. Al-Awadhi. Aerobiologia, 34, 325-336 (2018)

10. M. Ahmed, M. Al-Dousari, Ku. J. Sci. 40, 165-178 (2013)

11. M. Ahmed, N. Al-Dousari, A. Al-Dousari, Arab. J. Geosci. 9, 134 (2016)

12. M. Ahmed, A.M. Al-Dousari, J. Agri. Sci. Tech. 5, 81-89 (2015)

13. A. Al-Dousari, D. Doronzo, M. Ahmed, Sustainability, 9, $1526 \quad$ (2017). doi.org/10.3390/su9091526

14. R. Misak, A. Al-Dousari, S. Al-Hagraf, Int. Conf. desertification control in the arid regions, 12-15 (2007)

15. A. M. Al-Dousari, in Desertification in arid lands: causes, consequences and mitigation. Kuwait Institute for Scientific Research, Kuwait, 137-148 (2009)

16. J. Al Awadhi, A. Al-Dousari, F.I. Khalaf, Atmos. Climate Sci. 3, 10 (2014)

17. M. Al-Dousari, A. Al-Hazza, Arab. J. Geosci, 6, 519527 (2013)

18. A. Al-Dousari, K. Pye, A Al-Hazza, F Al-Shatti, M. Ahmed, N. Al-Dousari, J. Nanopart. Res. 22, 1-15 (2020)

19. A. Al-Dousari, A. Ramadan, A. Al-Qattan, S. AlAteeqi, H. Dashti, M. Ahmed, J. Taibah Univ. Sci. 14, 628-639 (2020)

20. E. Al-Enezi, A. Al-Dousari, F. Al-Shammari, J. Eng. Res. 2, 1-14 (2014)

21. A. Al-Dousari, A.K. Al-Enezi, J. Al-Awadhi, Arab. J. Geosci. 1, 17-31 (2008)

22. A. Al-Dousari, M. Ahmed, M. Senafy, M. Al Mutairi, Ku. J. Sci. Eng. 35, 129-150 (2008)

23. F. Khalaf, R. Misak, A. Al-Dousari, Arab. J. Arid Env. 29, 267-292 (1995)

24. A. Al-Dousari, M. Ahmed, N. Al Dousari, S. Al Awadhi, in Exploring the nexus of geoecology, geography, geoarcheology: Advances and application for sustainable development in Environmental sciences and Agroforestry Research, Springer Cham, 43-46 (2019)

25. J. M. Al-Awadhi, A. Al-Dousari, Int. J. Earth Sci. 102, 949-958 (2013)

26. M. Ahmed, A. Al-Dousari, J. Agri. Sci. Tech. 7, 100110 (2017)

27. N. Middleton, and D.S.G. Thomas. 2nd ed. London and New York: UNEP/Edward Arnold, 1997. 